\title{
Sutural Diastasis Caused by Pseudotumor Cerebri
}

\section{Psödotümör Serebri Nedeniyle Gelişen Sütüral Ayrısma}

\author{
Saim KAZAN, Tanju UCAR, Umut TURGUT \\ Akdeniz University, Faculty of Medicine, Department of Neurosurgery, Antalya, Turkey
}

Correspondence address: Saim KAZAN / E-mail: skazan@akdeniz.edu.tr

\begin{abstract}
The diagnosis of pseudotumor cerebri is based on the triad of: (1) papilloedema, (2) elevated intracranial pressure with a normal cerebrospinal constituency and (3) normal central nervous system imaging studies. However, the diagnosis of pseudotumor cerebri is not always straightforward. We report a 19-year-old morbidly obese girl who developed pseudotumor cerebri associated with sutural diastasis of the cranium based on the direct radiographies. Following a ventriculo-peritoneal shunt operation, we demonstrated the closing and perisuturally sclerosis on all major cranial sutures. A careful examination of direct radiographies might be critical for diagnosis of pseudotumor cerebri. Prompt recognition, evaluation, and treatment are needed to prevent permanent visual loss.
\end{abstract}

KEYWORDS: Pseudotumor cerebri, Sutural diastasis, Intracranial pressure

\section{Öz}

Psödotümör serebri tanısı genellikle; 1) papilödemi 2) Normal beyin omurilik sıvısı içeriği ve artmış intrakranial basınç 3) Normal santral sinir sistemi görüntülemesi triadı ile konur. Buna rağmen tanıya varmak her zaman kolay değildir. Biz yazımızda 19 yaşında, ileri obez bir kızda direkt radyografilerde göze çarpan sütüral ayrışmanın eşlik ettiği bir psödotümör olgusunu sunuyoruz. Ventrikülo-peritoneal shunt operasyonundan sonra tüm major kraniyal sütürlerde kapanma ve perisütüral sklerozu gösterdik. Direkt kafa grafilerinin dikkatli değerlendirilmesi tanıda kritik öneme sahiptir. Uygun tanı, değerlendirme ve tedavi kalıcı görme kayıplarının önüne geçmektedir.

ANAHTAR SÖZCÜKLER: Psödotümör serebri, Sütüral ayrışma, İntrakraniyal basınç

\section{INTRODUCTION}

Pseudotumor cerebri (PTC), also known as idiopathic intracranial hypertension, is a syndrome characterized by increased intracranial pressure (ICP), normal cerebrospinal fluid content, a normal brain, normal or small ventricles seen on imaging studies and excludes underlying structural and systemic causes (1). The features of this condition that typically affects young obese women are headache, visual disturbance and papilloedema (2). The origin and pathophysiological mechanisms of this condition have been the source of controversy for many years. The potential mechanisms underlying PTC have included disturbance of cerebrospinal fluid (CSF) circulation, increased rate of CSF production, increased sagittal sinus venous pressure and cerebral blood volume and swelling caused by diffuse brain edema (3).

\section{CASE REPORT}

A 19-year-old morbidly obese girl was admitted to our department with the complaints of severe headache and diplopia. She had a three-year history of PTC uncontrolled by medication including carbonic anhydrase inhibitors and by lumbar puncture. In neurological examinations we found diplopia at bilateral horizontal vision and papilloedema. Her cranial magnetic resonance imaging(MRI) was normal, however, it was demonstrated left lateral sinus retrograde filling by MRI venography (Figure 1A, B). Interestingly, there was a separation on coronal, lambdoid and sagittal sutures on her direct cranial radiographies (Figure 2A, B). The opening pressure of CSF on lumbar puncture was found to be $37 \mathrm{~cm}$ CSF with normal composition. We performed a ventriculoperitoneal (VP) shunt operation to the patient. Following the VP shunt, all related symptoms and complaints of the patient were resolved. In addition, we demonstrated the closing and perisuturally sclerosis on all major cranial suturas (Figure 3A, B).

\section{DISCUSSION}

While the sutural diastasis could be seen due to the high ICP by multifactorial causes such as intracranial tumor, hydrocephalus, head trauma or other structural, systemic and infectious causes, especially in new born babies and infants, the sutural diastasis of the cranium due to PTC in neither young nor adult patients has been reported up to now as far as we know. Development of cranium and closing of major sutures continues until 12 years old, the ossification of cranial sutures and complete closing of the sutures is a period which continues until the fourth decade (4). It was stated that the diagnosis of early changes of sutural diastasis is difficult, particularly in the very young whose ossification is incomplete. Especially, the superior segment of the coronal suture may remain open during childhood, care should be taken not to base a diagnosis of increased ICP solely on the 


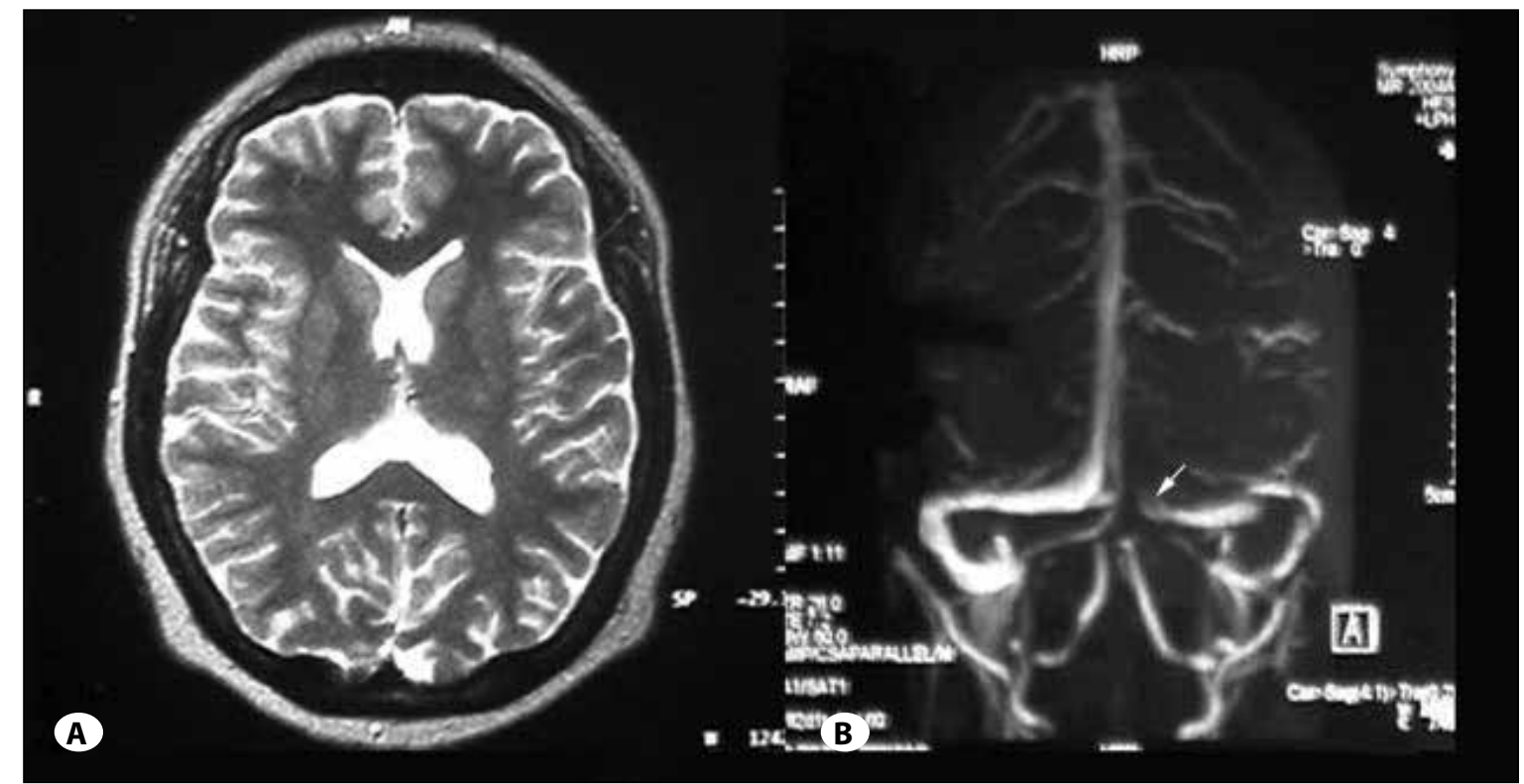

Figure 1: Cranial T2-weighted Magnetic Resonance Imaging (A) and Magnetic Resonance Imaging venography demonstrating left lateral sinus retrograde filling (arrow) (B).

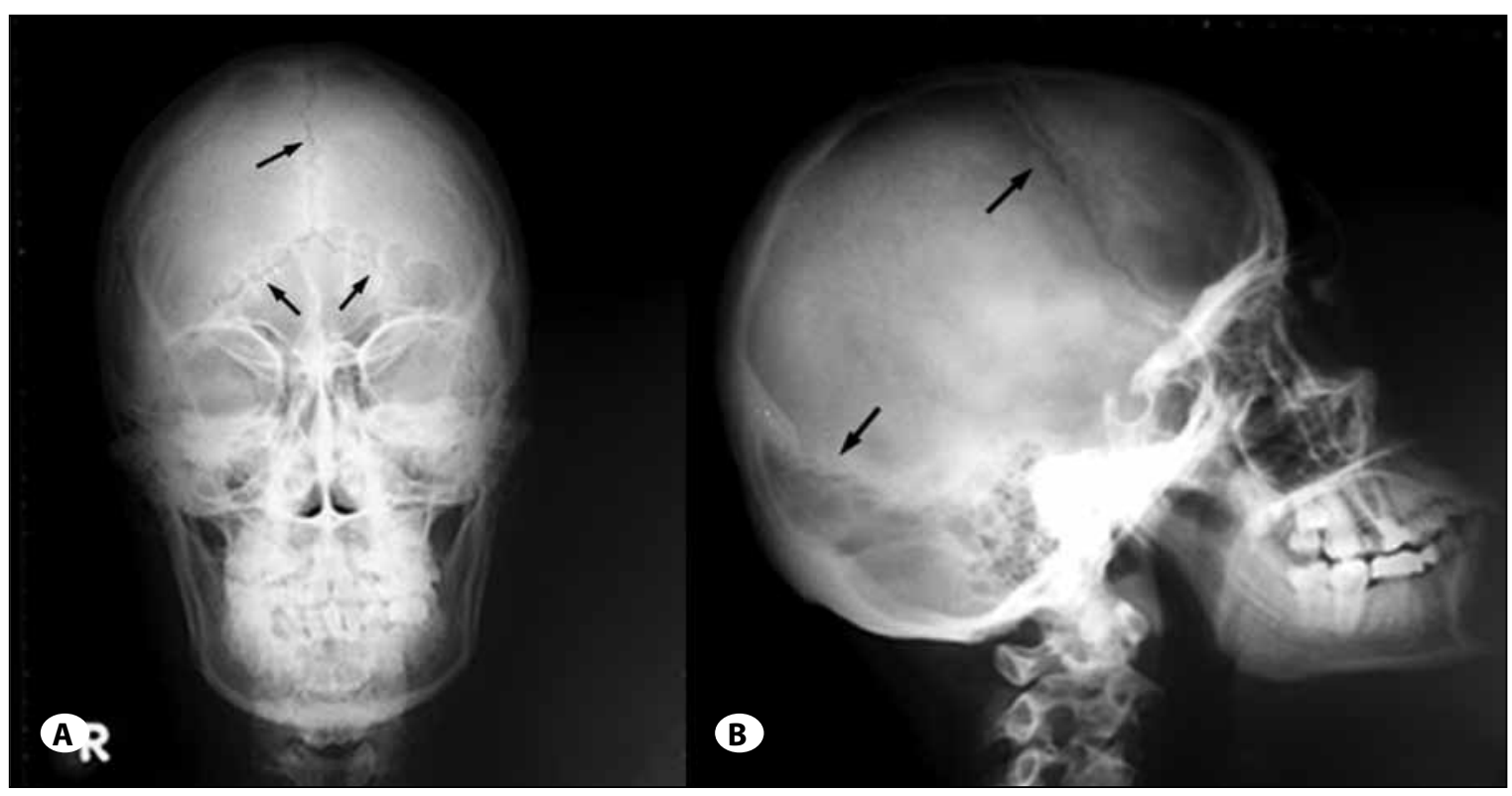

Figure 2: Anteroposterior (A) and lateral (B) cranial radiographies showing sutural diastasis on all major sutures. 


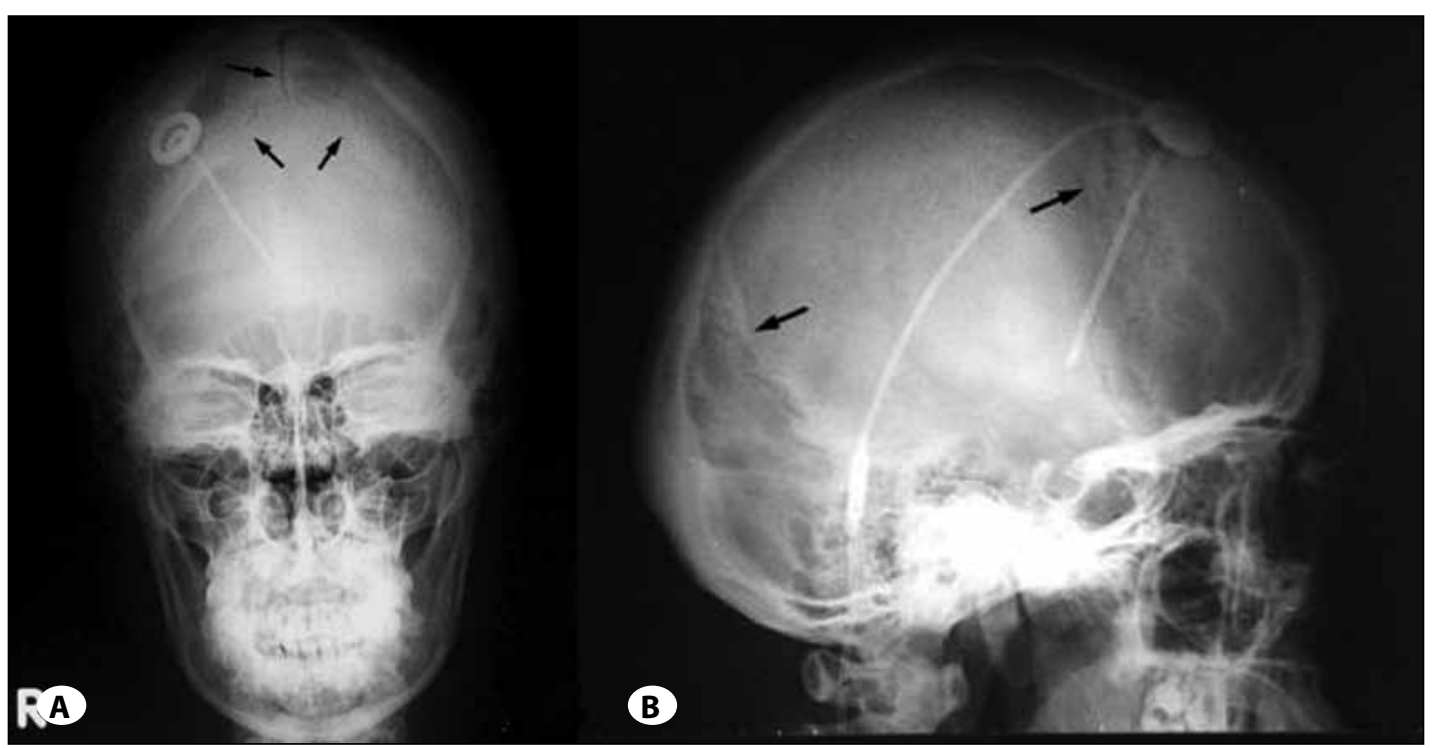

Figure 3: Anteroposterior (A) and lateral (B) cranial radiographies showing the closing and perisuturally sclerosis on all major cranial sutures after a ventriculo-peritoneal shunt operation.

appearance of this structure (4). The diastasis was on all major sutures in this patient. Finally, more careful examination of direct craniographies along with data from other imaging techniques and clinical findings might be recommended for the diagnosis of pseudotumor cerebri.

\section{REFERENCES}

1. Bastin ME, Sinha S, Farrall AJ, Wardlaw JM, Whittle IR: Diffuse brain edema in idiopathic intracranial hypertension: A quantitative magnetic resonance imaging study. J Neurol Neurosurg Psychiatry 74:1693-1696, 2003
2. Cinciripini GS, Donahue S, Borchert MS: Idiopathic intracranial hypertension in prepubertal pediatric patients: Characteristics, treatment and outcome. Am J Ophthalmol 127:178-182, 1999

3. Owler BK, Parker G, Halmagyi GM, Dunne VG, Grinnel V, McDowell D, Beser M: Pseudotumor cerebri syndrome: Venous sinus obstruction and its treatment with stent placement. J Neurosurg 98:1045-1055, 2003

4. Schechter MM: Radiology of the skull, in Youmans JR(ed): Neurological Surgery. Philadelphia: W. B. Saunders Company, 1982: $77-110$ 